\section{Response to: 'Eosinophilic granulomatosis with polyangiitis (Churg-Strauss) induced by immune checkpoint inhibitors' by Delyon et al}

We thank Delyon et al for their interest in our original paper ${ }^{1}$ and for reporting on a patient with immune checkpoint inhibitors (ICI)-induced eosinophilic granulomatosis with polyangiitis (EGPA). ${ }^{2}$ Since the first description in 2014 of giant cell arthritis (GCA) following treatment with ipilimumab (anti-CTLA-4 agent) in two patients with melanoma, ${ }^{3}$ several vasculitis cases have been reported, as recently highlighted by Daxini et al in a systematic literature review. ${ }^{4}$ Overall, they compiled 20 cases of confirmed ICI-induced vasculitis, which were classified using the revised International Chapel Hill Consensus Conference nomenclature. The most commonly reported types of vasculitis were large vessel vasculitis and vasculitis of the nervous system, with a median exposure time to ICI of 3 months. The majority of patients received oral or intravenous corticosteroids and ICI was discontinued. Of note, a granulomatosis with polyangiitis occurred 1 week following anti-programmed cell death 1 (PD-1) agent for advanced melanoma, requiring methylprednisolone and oral daily cyclophosphamide. ${ }^{5}$ Unfortunately, data on cancer and vasculitis outcomes are often missing.

By adding the first case report of EGPA, Delyon et al complete the unique and expanding list of ICI-related adverse events (irAEs). Interestingly, antineutrophil cytoplasmic antibodies were negative, similar with findings in other rheumatic irAEs such as myositis and inflammatory arthritis where autoantibodies are often negative, which should not exclude the diagnosis. Therefore, rheumatologists as well as other organ specialists involved in the diagnosis and management of irAEs have to consider vasculitis when evaluating patients receiving ICI. Notably, since polymyalgia rheumatica-like syndrome is frequently reported with anti-PD-(L) 1 therapies, ${ }^{6}$ we should pay particular attention to GCA symptoms.

On the other hand, Zhang et al reported an insufficient negative signalling by the immune checkpoint PD-1/PD-L1 in the pathogenesis of GCA. ${ }^{7}$ Indeed, they demonstrated low expression of PD-L1 in GCA dendritic cells compared with healthy arteries, unleashing PD- $1^{\text {high }} \mathrm{T}$ cells to infiltrate and damage the walls of large arteries. These data shed light on the association between vasculitis and the downregulation of PD-1/PD-L1 pathway, either spontaneous or induced by ICI, and may suggest future therapeutic immunomodulatory approaches in our classical vasculitis.
Marie Kostine, Thierry Schaeverbeke, on behalf of the FHU-ACRONIM

Department of Rheumatology, Centre Hospitalier Universitaire, Bordeaux, France

Correspondence to Dr Marie Kostine, Department of Rheumatology, Centre Hospitalier Universitaire, Bordeaux 33000, France; marie.kostine@chu-bordeaux.fr

Handling editor Josef S Smolen

Collaborators FHU-ACRONIM: Aquitaine's Care And Research Organisation For Inflammatory And Immune-Mediated Diseases.

Contributors MK drafted the manuscript. TS critically reviewed and approved the final version of the manuscript.

Competing interests None declared.

Patient consent Not required.

Provenance and peer review Commissioned; internally peer reviewed.

(c) Author(s) (or their employer(s)) 2019. No commercial re-use. See rights and permissions. Published by BMJ.

\section{Check for updates}

To cite Kostine M, Schaeverbeke T, on behalf of the FHU-ACRONIM. Ann Rheum Dis 2019:78:e83.

Received 16 July 2018

Revised 17 July 2018

Accepted 18 July 2018

Published Online First 27 July 2018

\section{SLinked}

- http://dx.doi.org/10.1136/annrheumdis-2018-213857

Ann Rheum Dis 2019;78:e83. doi:10.1136/annrheumdis-2018-213895

\section{REFERENCES}

1 Kostine M, Rouxel L, Barnetche T, et al. Rheumatic disorders associated with immune checkpoint inhibitors in patients with cancer-clinical aspects and relationship with tumour response: a single-centre prospective cohort study. Ann Rheum Dis 2018;77:393-8.

2 Roger A, Groh M, Lorillon G, et al. PATIO group. Eosinophilic granulomatosis with polyangiitis (Churg-Strauss) induced by immune checkpoint inhibitors. Ann Rheum Dis 2019;78:e82

3 Goldstein BL, Gedmintas L, Todd DJ. Drug-associated polymyalgia rheumatica/giant cell arteritis occurring in two patients after treatment with ipilimumab, an antagonist of ctla-4. Arthritis Rheumatol 2014;66:768-9.

4 Daxini A, Cronin K, Sreih AG. Vasculitis associated with immune checkpoint inhibitors-a systematic review. Clin Rheumatol 2018.

5 van den Brom RR, Abdulahad WH, Rutgers A, et al. Rapid granulomatosis with polyangiitis induced by immune checkpoint inhibition. Rheumatology 2016;55:1143-5

6 Belkhir R, Burel SL, Dunogeant L, et al. Rheumatoid arthritis and polymyalgia rheumatica occurring after immune checkpoint inhibitor treatment. Ann Rheum Dis 2017;76:1747-50

7 Zhang H, Watanabe R, Berry GJ, et al. Immunoinhibitory checkpoint deficiency in medium and large vessel vasculitis. Proc Natl Acad Sci U S A 2017;114:E970-E979. 